\title{
Protein and arginine requirements for maintenance and nitrogen gain in four teleosts
}

\author{
V. Fournier ${ }^{1}$, M. F. Gouillou-Coustans ${ }^{2}$, R. Métailler ${ }^{2}$, C. Vachot $^{1}$, M. J. Guedes ${ }^{3}$, F. Tulli ${ }^{4}$, \\ A. Oliva-Teles ${ }^{3}$, E. Tibaldi ${ }^{4}$ and S. J. Kaushik ${ }^{1 *}$ \\ ${ }^{1}$ Laboratoire de Nutrition des Poissons, Unité mixte INRA-IFREMER, Unité d'Hydrobiologie, B.P. 3, 64310 St Pée sur \\ Nivelle, France \\ ${ }^{2}$ Laboratoire de Nutrition des Poissons, Unité mixte INRA-IFREMER, Centre de Brest, B.P. 70. 29280 Plouzané, France \\ ${ }^{3}$ Faculdade de Ciências do Porto, CIIMAR, Pr. Gomes Teixeira, 4099-002 Porto, Portugal \\ ${ }^{4}$ Dipartimento di Scienze della Produzione Animale, via S. Mauro 2, 33010 Pagnacco (UD), Italy
}

(Received 20 February 2001 - Revised 7 January 2002 - Accepted 14 January 2002)

\begin{abstract}
Besides being an indispensable amino acid for protein synthesis, arginine (Arg) is also involved in a number of other physiological functions. Available data on the quantitative requirement for Arg in different teleosts appear to show much variability. So far, there are very limited data on the maintenance requirements of indispensable amino acids (IAA) in fish. In the present study, we compared $\mathrm{N}$ and Arg requirements for maintenance and growth of four finfish species: rainbow trout (Oncorhynchus mykiss), turbot (Psetta maxima), gilthead seabream (Sparus aurata) and European seabass (Dicentrarchus labrax). Groups of fish having an initial body weight close to 5-7g were fed semi-purified diets containing graded levels of $\mathrm{N}$ (0 to $8 \% \mathrm{DM}$ ) and $\operatorname{Arg}(0$ to $3 \% \mathrm{DM})$ over 4 to 6 weeks. For each species, $\mathrm{N}$ and Arg requirements for maintenance and for growth were calculated regressing daily $\mathrm{N}$ gain against daily $\mathrm{N}$ or Arg intakes. $\mathrm{N}$ requirement for maintenance was estimated to be $37 \cdot 8,127 \cdot 3,84.7$ and $45 \cdot 1 \mathrm{mg} / \mathrm{kg}$ metabolic body weight per $\mathrm{d}$ and $2 \cdot 3,2 \cdot 2,2.6$ and $2.5 \mathrm{~g}$ for $1 \mathrm{~g} \mathrm{~N}$ accretion, in rainbow trout, turbot, gilthead seabream and European seabass respectively. The four species studied appear to have very low or no dietary Arg requirements for maintenance. Arg requirement for $\mathrm{gN}$ accretion was calculated to be $0.86 \mathrm{~g}$ in rainbow trout and between $1.04-1.11 \mathrm{~g}$ in the three marine species. Turbot required more $\mathrm{N}$ for maintenance than the other three species, possibly explaining its reputedly high overall dietary protein requirement. Data suggest a small but sufficient endogenous Arg synthesis to maintain whole body $\mathrm{N}$ balance and differences between freshwater and marine species as regards Arg requirement. It is worth verifying this tendency with other IAA.
\end{abstract}

Requirement: Maintenance: Growth: Nitrogen: Arginine: Teleosts

One common feature of most aquatic animals is the high dietary protein requirement (30-65\% DM; Nutrition Research Council, 1993) making teleosts appear as distinct from other animals cultivated for human food. Significant inter-species differences with regard to protein requirements also appear to exist in fish. Given the increase in aquaculture production and the implications of poor protein utilisation on nitrogenous losses in the effluents, there is an increasing need for optimising protein and indispensable amino acid (IAA) supply. Further, given the variety of species under cultivation, there is also a need for knowledge on possible differences between the various fish species.

A critical analysis of existing data on amino acid (AA) requirements of different species of fishes shows similarities as well as differences (Tacon \& Cowey, 1985; Cowey, 1994; Kaushik, 1995). The variations in the IAA requirement of fishes can be attributed to a number of

\footnotetext{
Abbreviations: AA, amino acid; Arg, arginine; DAA, dispensable amino acid; DGC, daily growth coefficient; FBW, final body weight; FE, feed efficiency; $\mathrm{HA}^{-}$, arginine-free high-protein diet; HP, high-protein diet; IAA, indispensable amino acid; IBW, initial body weight; $\mathrm{LA}^{-}$, arginine-free low-protein diet; LP, low-protein diet; $\mathrm{MA}^{-}$, arginine-free medium-protein diet; MBW, metabolic body weight; MP, medium-protein diet; OUC, ornithine-urea cycle; PER, protein efficiency ratio; PF, protein-free diet; SAA, sulfur amino acid; VFI, voluntary feed intake.
}

*Corresponding author: Dr S. J. Kaushik, fax +33 5595451 52, email kaushik@st-pee.inra.fr 
factors such as differences in basal diet composition, size and age of fish, genetic differences, feeding rate and culture conditions, all of which affect overall growth rate besides experimental design and choice of response criterion (Cowey, 1994; Mambrini \& Kaushik, 1995a).

While data on protein requirements for maintenance are available for a few freshwater (Kaushik et al. 1981; Kaushik \& Luquet, 1984) and marine species (Lupatsch et al. 1998), data on the maintenance requirements for IAA are scarce. For estimating the AA requirements for maintenance of pigs, Fuller et al. (1989) proposed a linear model based on the relationship between AA intake and $\mathrm{N}$ gain. This method involves regression of daily $\mathrm{N}$ gain (protein accretion) $v$. daily AA intake, where the $x$-intercept of the regression represents the amount of the given IAA required for maintaining $\mathrm{N}$ balance and where the reciprocal of each regression coefficient represents the amount of AA needed to increase protein accretion by $1 \mathrm{~g}$. Using the foresaid approach, Mambrini \& Kaushik (1995b) estimated the maintenance requirement for sulfur AA (SAA) of rainbow trout and found that to be about two-fold higher than those of terrestrial omnivores, possibly indicating a different basal protein metabolism in fish. More recently, Rodehutscord et al. (1997) have estimated the maintenance requirement of rainbow trout for several IAA, through intrapolation of dose-response data to zero growth.
Arginine (Arg) is an IAA necessary for optimal growth of young fish (Wilson, 1989) and terrestrial animals (Visek, 1986). Of the IAA, data on Arg requirement show a greater degree of variation than others (Wilson, 1989; Cho et al. 1992), possibly due to its involvement in several metabolic pathways. Besides protein synthesis, Arg is related to ureagenesis, synthesis of proline, creatine, polyamine and nitric oxide. The versatile nature of Arg is also subject to much speculation as regards its role as a potent secretagogue affecting plasma insulin levels as well as growth hormone and somatomedin release in mammals as well as in fishes (Swanson, 1990; Mommsen, 2001).

The purpose of the present study was to evaluate $\mathrm{N}$ and $\mathrm{Arg}$ requirements for maintenance and for growth between four species: one euryhaline species, rainbow trout (Oncorhynchus mykiss) grown in freshwater; three marine species, i.e. turbot (Psetta maxima), gilthead seabream (Sparus aurata) and European seabass (Dicentrarchus labrax).

\section{Materials and methods \\ Experimental diets}

Diets for all the four species were identical and were manufactured in the same laboratory (IFREMER, Brest, France), using the same batch of ingredients. Seven semi-purified diets were formulated (Table 1) to contain

Table 1. Composition of the semi-purified experimental diets used for the determination of maintenance and growth requirements for nitrogen and for arginine (Arg) in the four species

\begin{tabular}{|c|c|c|c|c|c|c|c|}
\hline Diets... & PF & LP & MP & $\mathrm{HP}$ & $\mathrm{LA}^{-}$ & $\mathrm{MA}^{-}$ & $\mathrm{HA}^{-}$ \\
\hline $\mathrm{N}$ level (\% DM) & 0 & $2 \cdot 4$ & 4.8 & $8 \cdot 0$ & $2 \cdot 4$ & 4.8 & $8 \cdot 0$ \\
\hline Arg content (\% DM) & 0 & 1.0 & $2 \cdot 0$ & $3 \cdot 0$ & 0 & 1.5 & 2.5 \\
\hline \multicolumn{8}{|l|}{ Components (g/kg diet) } \\
\hline Basal casein mixture* & 0 & 0 & 150 & 250 & 0 & 150 & 250 \\
\hline L-amino acids mixture & 0 & 163.9 & $190 \cdot 2$ & 264.8 & 177.9 & $196 \cdot 1$ & 273.5 \\
\hline Dextrin† & 718.9 & $555 \cdot 0$ & $378 \cdot 7$ & $204 \cdot 1$ & $541 \cdot 0$ & $372 \cdot 8$ & 195.4 \\
\hline Cod-liver oilł & 90 & 90 & 90 & 90 & 90 & 90 & 90 \\
\hline Soya lecithin§ & 20 & 20 & 20 & 20 & 20 & 20 & 20 \\
\hline Vitamin mix\| & 50 & 50 & 50 & 50 & 50 & 50 & 50 \\
\hline Mineral mix & 50 & 50 & 50 & 50 & 50 & 50 & 50 \\
\hline$\alpha$-Cellulose ${ }^{\star \star}$ & 50 & 50 & 50 & 50 & 50 & 50 & 50 \\
\hline Agar§ & 10 & 10 & 10 & 10 & 10 & 10 & 10 \\
\hline Fish-protein concentrate†† & 10 & 10 & 10 & 10 & 10 & 10 & 10 \\
\hline Ethoxyquint & 0.15 & 0.15 & 0.15 & 0.15 & 0.15 & 0.15 & 0.15 \\
\hline \multicolumn{8}{|l|}{ Chemical composition } \\
\hline DM (\% diet) & 97.91 & 91.50 & 91.00 & 93.19 & 92.33 & 92.45 & 93.53 \\
\hline $\mathrm{N}(\% \mathrm{DM})$ & 0.23 & 2.54 & 5.49 & 8.13 & 2.43 & $5 \cdot 37$ & 8.09 \\
\hline Fat (\% DM) & $10 \cdot 61$ & 10.53 & 11.61 & 11.85 & $10 \cdot 88$ & $10 \cdot 40$ & 11.57 \\
\hline Ash (\% DM) & 4.69 & 4.87 & 4.98 & $5 \cdot 31$ & 4.94 & $5 \cdot 10$ & $5 \cdot 27$ \\
\hline Energy (kJ/g DM) & $19 \cdot 15$ & $20 \cdot 14$ & $21 \cdot 11$ & 21.43 & $19 \cdot 89$ & $20 \cdot 88$ & 21.39 \\
\hline
\end{tabular}

PF, protein-free diet; LP, low-protein diet; MP, medium-protein diet; LA ${ }^{-}$, Arg-free low-protein diet; $\mathrm{MA}^{-}$, Arg-free medium-protein diet; $\mathrm{HA}^{-}$, Arg-free high-protein diet.

${ }^{*}$ Basal casein mixture contained: 70\% casein, vitamin-free (ICN Biochemicals, Orsay, France; no. 904798); $20 \%$.

† Dextrin, Sigma (St Quentin Fallavier, France) D2256; ethoxyquin, Sigma E8260.

$\ddagger$ La lorientaise des produits de la pêche, Lorient, France.

$\S$ Louis François, St Maur, France.

II Supplied the following according to National Research Council (1993) (to provide g/kg mixture, except as noted): retinyl acetate $(500000 \mathrm{IU} / \mathrm{g}), 0.5$; ascorbyl phosphate $(25 \%)$, 20; cholecalciferol $(500000 \mathrm{IU} / \mathrm{g}), 0.5$; tocopheryl acetate $(500 \mathrm{lU} / \mathrm{g})$, 10; menadione, 1; thiamin, 0.1 ; riboflavin, 0.4 ; pyridoxine, 0.3 ; calcium-pantothenate, 2 ; vitamin $B_{12}$, 1 ; niacin, 1 ; biotin (2\%), 1; folic acid, 0.1; choline (50\%), 200; inositol, 30.

I Supplied the following (to provide $\mathrm{g} / \mathrm{kg}$ mixture, except as noted): magnesium carbonate, 124; calcium carbonate, 215; potassium chloride, 90 ; sodium chloride, 40 ; potassium iodide, $40 \mathrm{mg}$; copper sulfate, 3 ; cobalt sulfate, $20 \mathrm{mg}$; ferric sulfate, 20 ; manganese sulfate, 3; zinc sulfate, 4; dibasic calcium phosphate, 500; sodium fluoride, 1.

${ }^{* *}$ Arbocel BOO, J. Rettenmaier \& Söhne, Ellwangen Hotzmühle, Deutschland.

†† CPSP, Sopropêche, Lorient, France. 
Table 2. Composition of the L-amino acids* mixtures ( $\mathrm{g} / \mathrm{kg}$ diet) used in the semi-purified dietst

\begin{tabular}{|c|c|c|c|c|c|c|}
\hline Diets... & LP & MP & $\mathrm{HP}$ & $\mathrm{LA}^{-}$ & $\mathrm{MA}^{-}$ & $\mathrm{HA}^{-}$ \\
\hline Arginine & $9 \cdot 4$ & $15 \cdot 7$ & $23 \cdot 2$ & 0 & $11 \cdot 8$ & $17 \cdot 4$ \\
\hline Histidine & 3.9 & 4.0 & 5.4 & 3.9 & 4.0 & 5.4 \\
\hline Isoleucine & $6 \cdot 6$ & $6 \cdot 7$ & $9 \cdot 1$ & $6 \cdot 6$ & $6 \cdot 7$ & $9 \cdot 1$ \\
\hline Leucine & $11 \cdot 0$ & $9 \cdot 3$ & $12 \cdot 1$ & $11 \cdot 0$ & $9 \cdot 3$ & $12 \cdot 1$ \\
\hline Lysine & $11 \cdot 3$ & $13 \cdot 3$ & $18 \cdot 6$ & $11 \cdot 3$ & $13 \cdot 3$ & $18 \cdot 6$ \\
\hline DL-Methionine & $4 \cdot 0$ & $3 \cdot 3$ & 4.2 & 4.0 & $3 \cdot 3$ & $4 \cdot 2$ \\
\hline Cystine & 1.5 & 2.5 & 3.7 & 1.5 & 2.5 & $3 \cdot 7$ \\
\hline Phenylalanine & $6 \cdot 6$ & $6 \cdot 0$ & $7 \cdot 8$ & $6 \cdot 6$ & $6 \cdot 0$ & $7 \cdot 8$ \\
\hline Tyrosine & 4.5 & $1 \cdot 1$ & 0.4 & 4.5 & $1 \cdot 1$ & 0.4 \\
\hline Threonine & $6 \cdot 8$ & 8.2 & 11.5 & $6 \cdot 8$ & 8.2 & 11.5 \\
\hline Tryptophan & 1.5 & 1.6 & $2 \cdot 2$ & 1.5 & 1.6 & $2 \cdot 2$ \\
\hline Valine & $7 \cdot 2$ & $5 \cdot 8$ & 7.5 & $7 \cdot 2$ & $5 \cdot 8$ & 7.5 \\
\hline Alanine & $12 \cdot 3$ & $21 \cdot 1$ & $31 \cdot 2$ & $15 \cdot 6$ & 22.4 & $33 \cdot 2$ \\
\hline Aspartic acid & $18 \cdot 4$ & $27 \cdot 7$ & $40 \cdot 3$ & $23 \cdot 2$ & $29 \cdot 7$ & $43 \cdot 2$ \\
\hline Glutamic acid & 28.6 & 27.5 & $36 \cdot 7$ & $36 \cdot 0$ & 30.6 & $41 \cdot 3$ \\
\hline Glycine & $13 \cdot 4$ & 24.9 & 37.4 & $16 \cdot 9$ & $26 \cdot 4$ & 39.5 \\
\hline Proline & 8.7 & $2 \cdot 7$ & 1.8 & 11.0 & 3.7 & $3 \cdot 2$ \\
\hline Serine & $8 \cdot 1$ & 8.6 & 11.8 & $10 \cdot 3$ & 9.5 & $13 \cdot 1$ \\
\hline Sum & $163 \cdot 9$ & $190 \cdot 2$ & $264 \cdot 8$ & $177 \cdot 9$ & $196 \cdot 1$ & 273.5 \\
\hline
\end{tabular}

LP, low-protein diet; MP, medium-protein diet; HP, high-protein diet; $\mathrm{LA}^{-}$, arginine-free low-protein diet; $\mathrm{MA}^{-}$, arginine-free medium-protein diet; $\mathrm{HA}^{-}$, arginine-free high-protein diet.

* All amino acids were provided by Eurolysine, Amiens, France.

†For details of diets and procedures, see Table 1 and p. 460.

graded levels of $\mathrm{N}$ and Arg, supplied by raw materials and a balanced mixture of L-amino acids (Table 2). The AA composition of the diets (Table 3) was based on the AA composition of fishmeal taken as reference for both IAA and dispensable amino acid (DAA) composition of the diets and met the IAA requirements of fish according to National Research Council (1993). Protein-free (PF), low-protein (LP), medium-protein (MP) and high-protein (HP) diets contained $0,2.4,4.8$ and $8 \%$ respectively of
$\mathrm{N}$ and were used to determine the protein requirements for maintenance and growth. Three further diets $\left(\mathrm{LA}^{-}\right.$, $\mathrm{MA}^{-}$, and $\mathrm{HA}^{-}$) were formulated to describe the relationship between Arg intake and $\mathrm{N}$ gain. Diet $\mathrm{LA}^{-}$corresponded to diet LP but without Arg. Diets $\mathrm{MA}^{-}$and $\mathrm{HA}^{-}$corresponded to diets MP and HP but with reduced Arg levels.

In order to ensure an adequate feed intake of the semipurified diets, a fish protein soluble concentrate was included $(10 \mathrm{~g} / \mathrm{kg})$ in the diets. In the case of turbot, inosine, known to be a potent feeding stimulant (Mackie \& Adron, 1978), was also included (1 g/kg diet). The AA mixtures were coated with agar (Mambrini \& Kaushik, $1995 a$ ) before mixing with the other ingredients. Diets were pelleted, dried for $10 \mathrm{~min}$ at $80^{\circ} \mathrm{C}$ then at room temperature for $10 \mathrm{~min}$ in a fluid-bed drier, and sieved to $1.6-$ $2 \mathrm{~mm}$ diameter and kept at $4^{\circ} \mathrm{C}$. Ingredient and chemical composition of the experimental diets are summarised in Table 1.

\section{Fish}

Rainbow trout. Triplicate groups of eighty juvenile rainbow trout originating from an INRA stock, having an initial mean body weight (IBW) of $6.7 \pm 0.1 \mathrm{~g}$ were reared in $1 \mathrm{~m}^{3}$ circular glass fibre tanks (water volume: 300 litres; flow rate: $501 / \mathrm{min}$ ) for 4 weeks at a constant water temperature of $17 \pm 1^{\circ} \mathrm{C}$.

Turbot. Triplicate groups of sixty juvenile turbot (IBW: $5 \cdot 0 \pm 0 \cdot 1 \mathrm{~g}$ ) obtained from a private fish farm (France turbot, Noirmoutier, France) and acclimatised to the experimental conditions were each reared in tanks of 50 litre capacity for 4 weeks in thermoregulated $(17 \pm$ $1^{\circ} \mathrm{C}$ ) seawater (salinity 35 parts per thousand).

Table 3. Amino acid composition of the experimental diets, along with data on requirements for salmonids according to National Research Council $(1993)^{*}$

( $\mathrm{g} / \mathrm{kg}$ diet)

\begin{tabular}{|c|c|c|c|c|c|c|c|}
\hline Diets... & LP & MP & $\mathrm{HP}$ & $\mathrm{LA}^{-}$ & $\mathrm{MA}^{-}$ & $\mathrm{HA}^{-}$ & Requirement \\
\hline Arginine & 11 & 26 & 33 & 1 & 22 & 29 & 15 \\
\hline Histidine & 10 & 11 & 11 & 11 & 11 & 14 & 7 \\
\hline Isoleucine & 8 & 14 & 14 & 5 & 9 & 20 & 9 \\
\hline Leucine & 8 & 22 & 24 & 7 & 16 & 21 & 14 \\
\hline Lysine & 13 & 29 & 35 & 13 & 29 & 42 & 18 \\
\hline Methionine & 3 & 6 & 6 & 4 & 6 & 6 & $10 \dagger$ \\
\hline Cystine & 3 & 8 & 8 & 3 & 6 & 9 & \\
\hline Phenylalanine & 15 & 13 & 14 & 4 & 13 & 16 & $18 \ddagger$ \\
\hline Tyrosine & 15 & 13 & 14 & 4 & 13 & 16 & \\
\hline Threonine & 7 & 13 & 19 & 6 & 17 & 17 & 8 \\
\hline Tryptophan & nd & nd & nd & nd & nd & nd & 2 \\
\hline Valine & 7 & 18 & 17 & 8 & 12 & 33 & 12 \\
\hline Alanine & 12 & 28 & 47 & 16 & 26 & 31 & \\
\hline Aspartic acid & 19 & 39 & 41 & 16 & 39 & 55 & \\
\hline Glutamic acid & 30 & 62 & 59 & 27 & 61 & 71 & \\
\hline Glycine & 10 & 23 & 31 & 6 & 34 & 43 & \\
\hline Serine & 7 & 16 & 25 & 11 & 17 & 21 & \\
\hline
\end{tabular}

LP, low-protein diet; MP, medium-protein diet; HP, high-protein diet; LA ${ }^{-}$, arginine-free low-protein diet; $\mathrm{MA}^{-}$, arginine-free medium-protein diet; $\mathrm{HA}^{-}$, arginine-free high-protein diet; nd, not determined.

${ }^{*}$ For details of diets and procedures, see Table 1 and p. 460.

† Methionine + cystine.

$\ddagger$ Phenylalanine+tyrosine. 

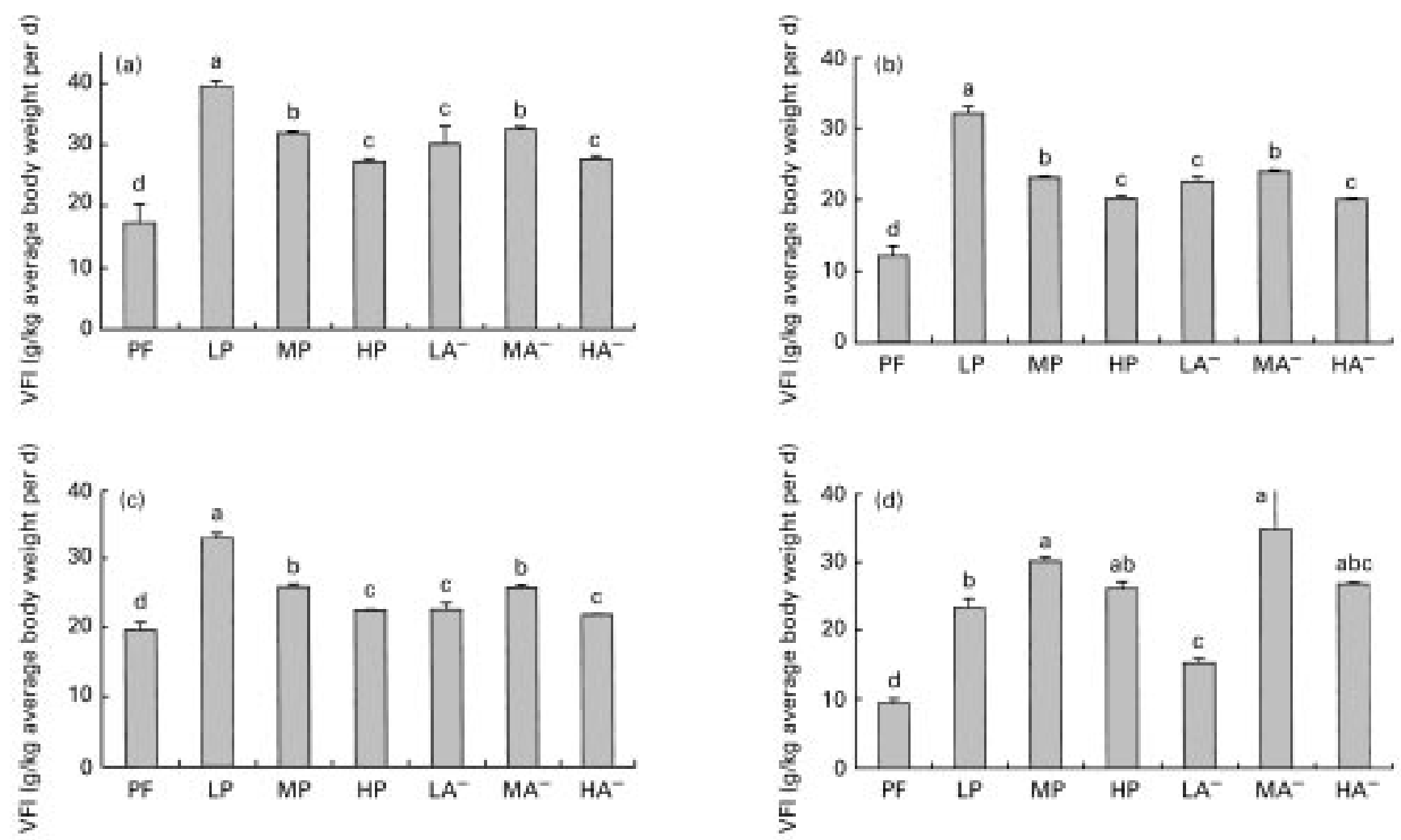

Fig. 1. Voluntary feed intake (VFI) in the four species as affected by dietary protein and arginine levels: (a) rainbow trout, $17^{\circ} \mathrm{C}$, initial body weight (IBW) $6.8 \mathrm{~g}$; (b) turbot, $17^{\circ} \mathrm{C}$, IBW $5.0 \mathrm{~g}$; (d) European seabass, $24^{\circ} \mathrm{C}$, IBW $5.0 \mathrm{~g}$; (d) gilthead seabream, $24^{\circ} \mathrm{C}$, IBW $7.4 \mathrm{~g}$. Values are mean values of three tanks and standard errors are represented by vertical bars. Mean values with unlike letters were significantly different, $P<0$.05. PF, protein-free diet; LP, low-protein diet; MP, medium-protein diet; HP, high-protein diet; LA ${ }^{-}$, arginine-free low-protein diet; MA ${ }^{-}$, arginine-free medium-protein diet; $\mathrm{HA}^{-}$, arginine-free high-protein diet.

European seabass. Fish originating from a private fish farm (Panittica pugliese, Torre Canne, Italy) were acclimatised to the experimental facilities. Triplicate groups of sixty juvenile seabass (IBW: $5 \cdot 0 \pm 0 \cdot 1 \mathrm{~g}$ ) were each reared in glass fibre tanks of 200 litre capacity for 6 weeks in recirculating, thermoregulated $\left(24 \pm 1{ }^{\circ} \mathrm{C}\right)$ seawater (salinity: 35 parts per thousand).

Gilthead seabream. Fish were obtained from a private fish farm and acclimatised to the experimental conditions. Duplicate groups of forty juvenile seabream (IBW: $7 \cdot 4 \pm 0.2 \mathrm{~g}$ ) were each reared in tanks of 250 litre capacity for 6 weeks in a recirculating and thermoregulated (24 \pm $1{ }^{\circ} \mathrm{C}$ ) seawater (salinity: 32 parts per thousand) system.

In all trials, fish were acclimatised to the experimental conditions over at least 2 weeks before the start of the feeding trials. Density of biomass was in tune with optimal growth conditions in the respective experimental culture facilities. Water temperature was set at the thermal preferendum allowing maximum growth rates of each species. Water quality and flow rates were maintained in order to supply sufficient $\mathrm{O}_{2}$ (above 8 parts per million) and to avoid build up of ammonia $\mathrm{N}$ (below $0 \cdot 1$ parts per million). The tanks were allocated at random to each test diet. The diets were manually distributed two to four times a day to visual satiety (visual observation of first feed refusal to ensure intake of all feed that was supplied). Mortality, if any, was recorded daily. At the end of the study, the fish were kept unfed for a $24 \mathrm{~h}$ period and then weighed in groups. Growth rate was estimated as daily growth coefficient (DGC, \%) as follows: $100 \times\left(\left(\mathrm{FBW}^{1 / 3}-\mathrm{IBW}^{1 / 3}\right) /\right.$ number of days) where FBW and IBW represent final and initial body weight respectively. Mean metabolic body weight $(\mathrm{MBW})$ was calculated as follows: $\mathrm{MBW}=$ $\left.\left(\left(\mathrm{IBW}^{0.75}\right)+\left(\mathrm{FBW}^{0.75}\right)\right) / 2\right)$.

For each species, a pooled sample of ten fish at the beginning and pools of ten fish per tank at the end of the feeding trial were withdrawn for whole body analysis. All the fish were killed by an excess of anaesthetic (ethylene glycol monophenyl ether) or cervical section. Although all fish had empty digestive tracts, they were checked and rinsed to avoid any possible contamination. Samples were kept frozen $\left(-20^{\circ} \mathrm{C}\right)$ until analysis.

\section{Body composition analysis}

Samples from each species were analysed using the same methodologies. Whole fish samples were ground and a sample was analysed for DM, before being freeze-dried and kept for further analyses. For both diets, as well as freeze-dried whole body samples, analyses were performed following usual laboratory procedures (Association of Official Analytical Chemists, 1984): DM $\left(110^{\circ} \mathrm{C}, 24 \mathrm{~h}\right)$, ash $\left(800^{\circ} \mathrm{C}, 24 \mathrm{~h}\right)$, fats (extraction with dichloroethane) and gross energy by adiabatic calorimetry. Crude protein $(\mathrm{N} \times$ 6.25) was determined using either the Dumas elemental analyser or the Kjeldahl method after acid digestion. 
Based on whole body composition analysis, daily $\mathrm{N}$ gains were calculated for all species. Dietary AA were analysed after hydrolysis $\left(6 \mathrm{M} \mathrm{HCl}, 110^{\circ} \mathrm{C}, 24 \mathrm{~h}\right.$, in vacuo $)$ of diet samples followed by evaporation (SpeedVac Labconco, Kansas City, USA), recovery in Li buffer and separation and post-column derivatisation with ninhydrine in an HPLC system (Waters 2690). Calculations were made using Millennium software version 3.0, St Quentin en Yvelines, France with norleucine as an internal standard.

\section{Data analysis}

All data were analysed by one-way ANOVA followed by the Newman-Keuls test, using the STAT-ITCF (1991) computing package. Differences between means were considered significant at $P<0 \cdot 05$. For determination of maintenance requirements for $\mathrm{N}$ and $\mathrm{Arg}$, two methods were used. Based on the method described by Fuller et al. (1989), the requirement for maintenance and growth were calculated using the coefficients $\mathrm{a}$ and $\mathrm{b}$ after a linear regression analysis $(y=\mathrm{a}+\mathrm{b} x)$ of data relating $\mathrm{N}$ or Arg intake to $\mathrm{N}$ gain: maintenance as $-\mathrm{a} / \mathrm{b}$ and $\mathrm{N}$ requirement for unit $\mathrm{N}$ gain as $1 / \mathrm{b}$, where $x=\mathrm{N}$ or Arg intake/kg MBW per $\mathrm{d}$ and $y=\mathrm{N}$ gain/kg MBW per $\mathrm{d}$. The relationship between Arg intake and $\mathrm{N}$ gain was also analysed using a four-parameter model described by Mercer (1982):

$$
Y=\frac{\mathrm{b}\left(K_{0.5}\right)^{\mathrm{n}}+R_{\max }(X)^{\mathrm{n}}}{\left(K_{0.5}\right)^{\mathrm{n}}+(X)^{\mathrm{n}}}
$$

where $Y$ is $\mathrm{N}$ gain $(\mathrm{mg} / \mathrm{kg} \mathrm{MBW}$ per d) $X$ is Arg intake $(\mathrm{mg} / \mathrm{kg} \mathrm{MBW}$ per $\mathrm{d}), \mathrm{b}$ is the intercept on the $Y$ axis, $R_{\max }$ is the maximal response, $K_{0.5}$ is the value of $X$ for $\frac{1}{2}\left(R_{\max }+\mathrm{b}\right)$ and $\mathrm{n}$ the apparent kinetic order. Graphical presentations and best-fits were made using a commercial PC software (GraphPad Prism Inc, San Diego, CA, USA).

\section{Results}

\section{Body-weight gain and feed efficiency}

Feed intake. In all the four species, mortality was very low $(<1 \%)$ and unaffected by dietary treatments and no external pathological signs were observed even in fish fed the PF or $\mathrm{LA}^{-}$diets. During the feeding trial, all diets were well accepted by the fish fed even diet PF and diet $\mathrm{LA}^{-}$(Fig. 1), except in turbot where, after 3 weeks, feed intake was reduced in fish fed diets $\mathrm{LA}^{-}$and PF. Voluntary feed intake (VFI, expressed as $\mathrm{g} / \mathrm{kg}$ average body weight per d) was high in fish fed the LP diet and decreased significantly $(P<0.05)$ with increasing dietary crude protein levels in rainbow trout, turbot and European seabass whereas in the gilthead seabream, VFI was not sig-
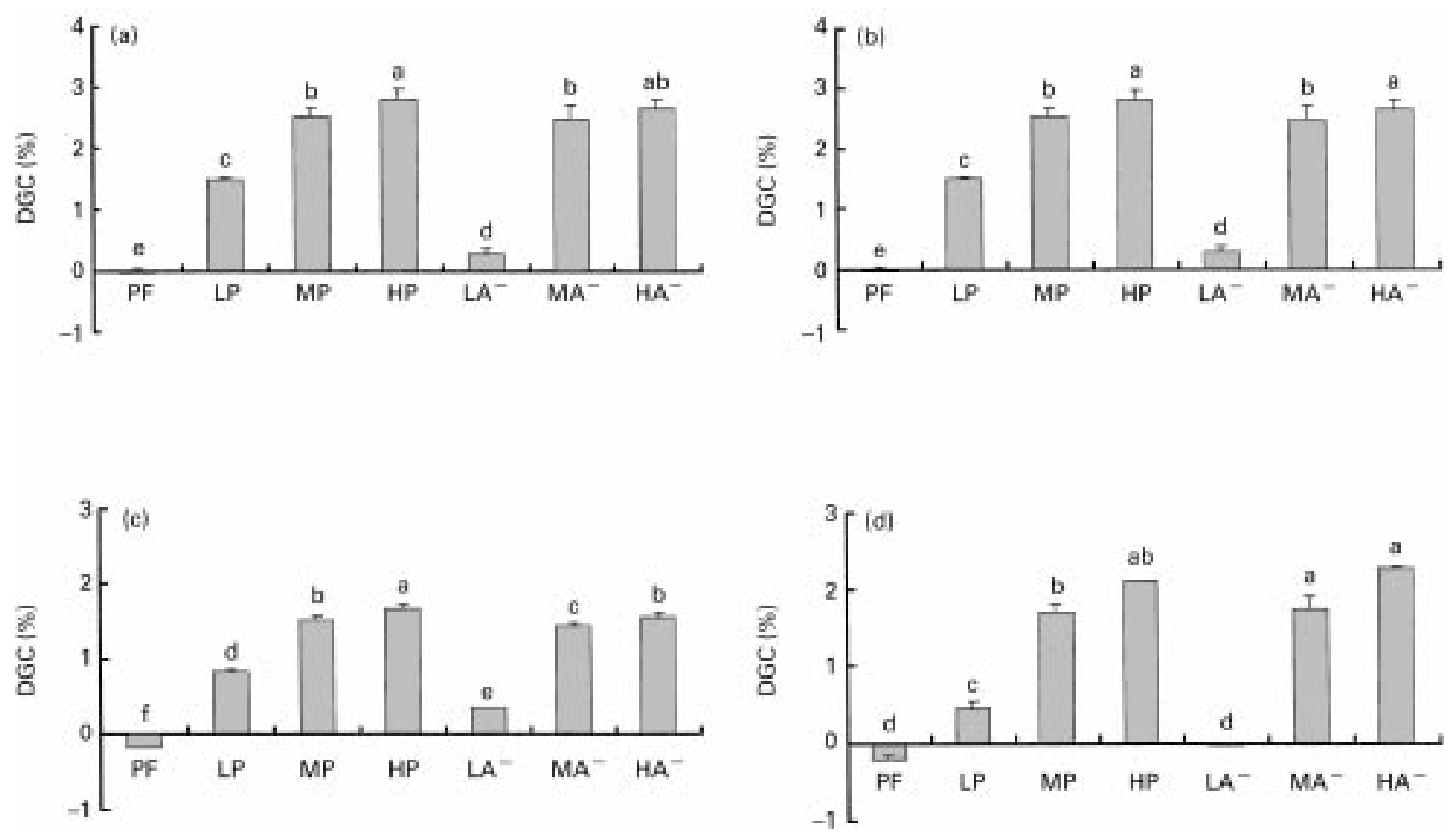

Fig. 2. Daily growth coefficient (DGC) in the four species as affected by dietary protein and arginine levels: (a) rainbow trout, $17^{\circ} \mathrm{C}$, initial body weight (IBW) $6.8 \mathrm{~g}$; (b) turbot, $17^{\circ} \mathrm{C}$, IBW $5.0 \mathrm{~g}$; (c) European seabass, $24^{\circ} \mathrm{C}$, IBW $5.0 \mathrm{~g}$; (d) gilthead seabream, $24^{\circ} \mathrm{C}$, IBW $7.4 \mathrm{~g}$. Values are mean values of three tanks and standard errors are represented by vertical bars. Mean values with unlike letters were significantly different, $P<0.05$. PF, protein-free diet; LP, low-protein diet; MP, medium-protein diet; HP, high-protein diet; LA ${ }^{-}$, arginine-free low-protein diet; MA ${ }^{-}$, arginine-free medium-protein diet; $\mathrm{HA}^{-}$, arginine-free high-protein diet. DGC was calculated as: $100 \times\left(\left(\mathrm{FBW}^{1 / 3}-\mathrm{IBW}^{1 / 3}\right) / \mathrm{number}\right.$ of $\left.\mathrm{d}\right) \mathrm{where}$ FBW and IBW represent final body weight and initial body weight respectively. 


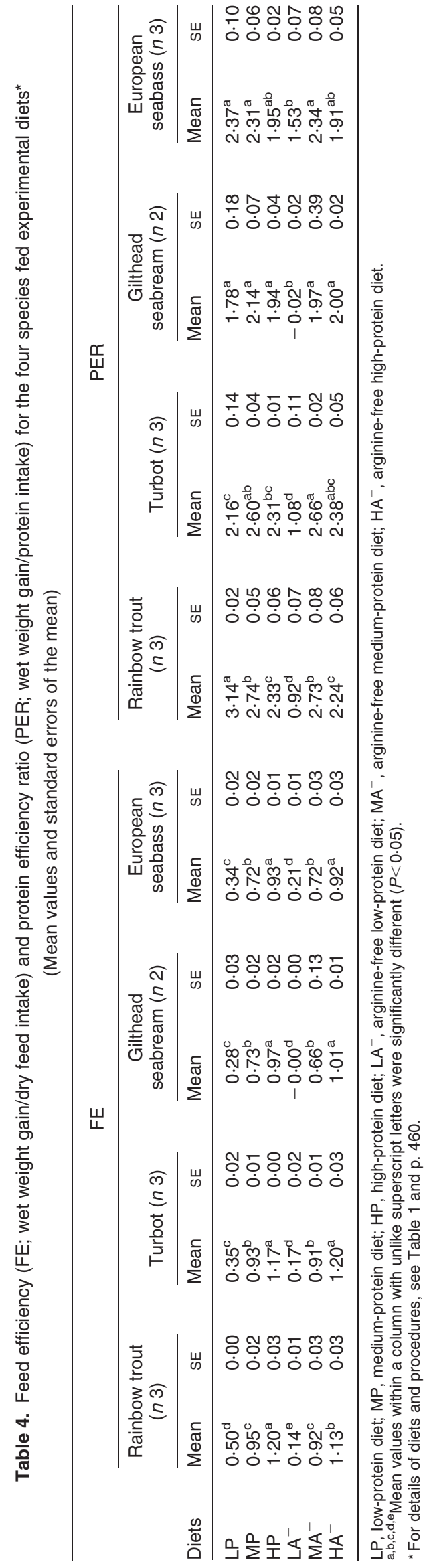

nificantly $(P>0.05)$ affected by dietary $\mathrm{N}$ level. In all the species, comparison of data between those fed MP or HP diets, and those fed diets with reduced Arg supply ( $\mathrm{MA}^{-}$ and $\mathrm{HA}^{-}$) showed that a partial reduction in dietary Arg levels did not have any significant effect $(P>0 \cdot 05)$ on VFI whereas the total suppression of $\operatorname{Arg}\left(\mathrm{LA}^{-} v\right.$. LP) led to a significant $(P<0.05)$ decrease of VFI.

Weight gain. Although fish fed diet PF showed a normal feeding behaviour during the trials, as expected, they showed significant body-weight loss. In all the four species, DGC were significantly $(P<0 \cdot 05)$ improved with increasing dietary protein and Arg levels (Fig. 2). At the low-protein level, the total absence of $\operatorname{Arg}$ (diet $\mathrm{LA}^{-}$) induced a reduction in or a total lack of body-weight gain. But at higher protein levels, a partial decrease in dietary Arg level did not lead to any significant reduction in weight gain except in seabass (Fig. 2).

Feed efficiency. In all species, feed efficiency (FE: wet weight gain/dry feed intake) increased significantly $(P<0.05)$ with an increase in the dietary $\mathrm{N}$ and Arg level (Table 4). Suppression of Arg led to a significant reduction of FE in all species $(P<0.05)$. A decrease in dietary Arg $\left(\mathrm{HA}^{-} v\right.$. HP and $\mathrm{MA}^{-} v$. MP) also had no effect on $\mathrm{FE}$ except in trout where there was a significant reduction in $\mathrm{FE}$ in fish fed HP compared with fish fed $\mathrm{HA}^{-}$.

Protein efficiency ratio (PER; wet weight gain/protein intake) was the highest in rainbow trout fed the LP diet $(2.4 \% \mathrm{~N}, 1 \% \mathrm{Arg})$ and was significantly affected by increasing dietary $\mathrm{N}$ level $(P<0.05)$. In turbot, gilthead seabream and European seabass, protein level did not significantly $(P>0.05)$ affect the PER value. In all species, PER decreased significantly with the suppression of Arg with a very strong effect for gilthead seabream $(P<0.05)$. But at medium and high dietary $\mathrm{N}$ levels, a decrease in dietary $\operatorname{Arg}\left(\mathrm{MA}^{-}\right.$and $\left.\mathrm{HA}^{-}\right)$had no significant effect on PER irrespective of the species $(P>0.05)$.

Protein requirement. The relationship between $\mathrm{N}$ intake and $\mathrm{N}$ gain for the four species fed PF, LP, MP and HP diets was analysed using both models. Given that the best fits were obtained with the linear model, the relationship was retained and illustrated in Fig. 3.

The linear relationship between daily $\mathrm{N}$ intake and daily $\mathrm{N}$ gain showed a very high degree of correlation for each of the species studied. Based on the linear regression model parameters, $\mathrm{N}$ requirements for maintenance and for growth were calculated for the four species (Table 5).

$\mathrm{N}$ requirement for maintenance was in the same range for rainbow trout and seabass (38 and $45 \mathrm{mg} / \mathrm{kg} \mathrm{MBW}$ per d respectively) whereas it was two-fold higher in seabream $(85 \mathrm{mg} / \mathrm{kg}$ MBW per d) and three-fold higher in turbot $(127 \mathrm{mg} / \mathrm{kg}$ MBW per d). $\mathrm{N}$ requirement for unit $\mathrm{N}$ gain was lower for turbot and rainbow trout $(2 \cdot 16$ and $2.28 \mathrm{~g} / \mathrm{g} \mathrm{N}$ gain respectively) than for European seabass and gilthead seabream $(2.53$ and $2.64 \mathrm{~g} / \mathrm{g} \mathrm{N}$ gain respectively).

Arginine requirement. Fig. 4 illustrates the relationship between Arg intake and $\mathrm{N}$ gain established by fitting the data obtained for the four species fed all diets except the PF diet. Both the linear model $(y=a x+b)$ and the nonlinear model (Mercer, 1982) for each species are depicted in Fig. 4. 


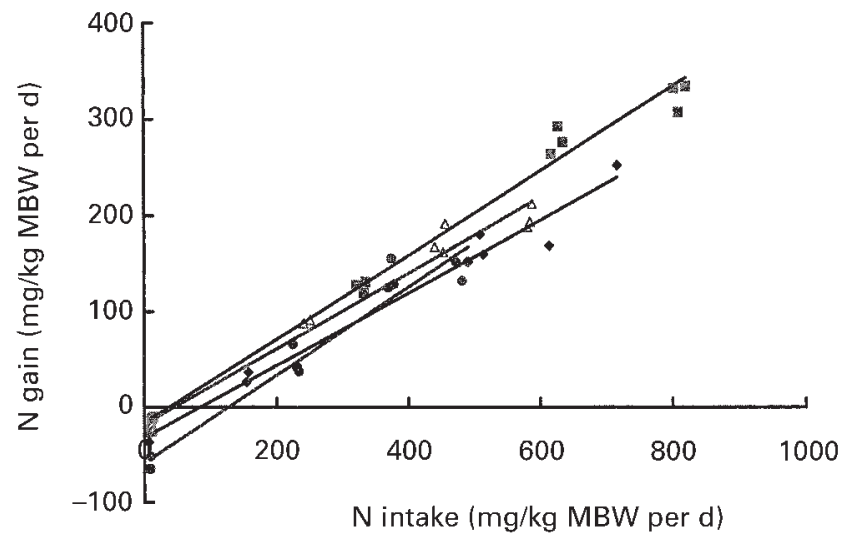

Fig. 3. Relationship between nitrogen intake and nitrogen gain in the four species. ( $\square$ ), rainbow trout: $y=-16.581+0.4388 x, R^{2}$ 0.9874 ; $(\bullet)$, turbot: $y=-58.84+0.4622 x, R^{2} 0.9508$; $(\Delta)$ seabass: $y=-17.866+0.3958 x, R^{2} 0.9723 ;(\diamond)$ seabream: $y=$ $-32.101+0.3791 x, R^{2} 0.9798$. Each point represents the mean nitrogen gain of the fish per tank. MBW, metabolic body weight $\left(\left(\mathrm{IBW}^{0.75}+\mathrm{FBW}^{0.75}\right) / 2\right)$ where FBW and IBW represent final body weight and initial body weight respectively.

Based on the linear relationship between daily Arg intake and daily $\mathrm{N}$ gain, Arg requirement for maintenance and for unit $\mathrm{N}$ gain were calculated according to Fuller et al. (1989) and the data are summarised in Table 6.

Data indicate either no (rainbow trout, turbot and European seabass) or very low (gilthead seabream) Arg requirement for maintenance. Arg requirement per unit protein accretion was very similar between the three marine species (166-178 mg) and slightly lower for the freshwater-grown rainbow trout $(138 \mathrm{mg})$.

\section{Discussion}

Following the general method as outlined by Fuller et al. (1989), the diets were formulated to contain two levels of Arg at each total $\mathrm{N}$ level. The AA profiles in the LP and $\mathrm{LA}^{-}$diets were chosen in order to simulate more or less the fish whole body AA composition, including those of DAA. Minor differences in the DAA profiles of diets are due to the fact that the partial or total suppression of Arg in the diets $\left(\mathrm{LA}^{-}, \mathrm{MA}^{-}\right.$and $\mathrm{HA}^{-}$) was compensated by a supply of DAA on an equivalent $\mathrm{N}$ basis of diets LP, MP and HP.

The good feed acceptance and excellent growth performance of the four species indicate that the semi-purified diets used in the present study were appropriate to determine nutrient requirements. Good performances with diets containing crystalline AA properly coated with agar have already been shown in rainbow trout (Cho et al. 1992; Rodehutscord et al. 1994) and in seabass (Tibaldi et al. 1994). An adjustment of the $\mathrm{pH}$ of diets containing high levels of crystalline AA has been found necessary for stomachless fish such as the common carp, whereas in all the four species studied here, preliminary studies had shown that this was not necessary.

The inverse relationship between VFI and dietary $\mathrm{N}$ level suggests that fish were able to partially compensate for low dietary protein supply by increasing their voluntary feed intake. Besides, rainbow trout fed the low-protein and low-Arg diet (LP) showed a two-fold increase in body weight with a very good PER value $(3 \cdot 14)$. These results indicate that this species has a low $\mathrm{N}$ and Arg requirement for maintenance and for growth. Low growth in all fish fed the diet devoid of Arg $\left(\mathrm{LA}^{-}\right)$indicate a clear Arg deficiency after the 4 or 6 weeks of the growth trial. The lack of growth in seabream suggests a higher Arg requirement for maintenance in this species compared with the other three species.

The reliability of the linear model as proposed by Fuller et al. (1989) for estimating maintenance requirements is based on high growth and positive $\mathrm{N}$ balance and necessarily involves short duration of the trials. Each species of fish had maximum growth rates very much similar to those obtained with practical diets based on fishmeal and the DGC were comparable to those reported earlier (Kaushik, 1998). In an earlier study on Arg requirement for growth of rainbow trout, Cho et al. (1992) have already used the four-parameter nutrient dose-response analysis to estimate the requirements. A comparison of regressions according to the four-parameter nutrient kinetics model of Mercer (1982) and the simple linear regression model as proposed by Fuller et al. (1989) was also made for describing the relationship between $\mathrm{N}$ intake and $\mathrm{N}$ gain as well as for the relationship between Arg intake and $\mathrm{N}$ gain (Fig. 4). As regards $\mathrm{N}$ intake and $\mathrm{N}$ gain, the responses were better expressed and the calculations for both maintenance and per unit $\mathrm{N}$ gain were better determined using the linear regression model (best-fit model, $P<0.05)$. Besides, given that only four dietary groups (PF, LP, MP and HP) were used in analyses, the linear regression model was more suitable than the four-parameter model.

In an earlier study on Arg requirement for growth of

Table 5. Nitrogen requirements for nitrogen balance and protein accretion in the four species calculated based on the method described by Fuller et al. (1989)*

\begin{tabular}{lcccc}
\hline & $\begin{array}{c}\text { N balance } \\
\text { N requirement for... }\end{array}$ & $\begin{array}{c}\text { Gnit gain } \\
(\mathrm{g} \mathrm{N} / \mathrm{g} \mathrm{N} \text { gain })\end{array}$ & $\mathrm{g}$ N/g protein gain & As times of maintenance \\
\hline Rainbow trout & 37.79 & 2.28 & 0.365 & 60.31 \\
Turbot & 127.30 & $2 \cdot 16$ & 0.346 & 16.99 \\
Gilthead seabream & 84.68 & 2.64 & 0.422 & 31.15 \\
European seabass & 45.14 & 2.53 & 0.404 & 55.97 \\
\hline
\end{tabular}

MBW, metabolic body weight $\left(\left(\mathrm{IBW}^{0.75}+\mathrm{FBW}^{0.75}\right) / 2\right)$; IBW, initial body weight $(\mathrm{kg})$; FBW, final body weight $(\mathrm{kg})$.

*For details of procedures, see p. 461, and for details of the calculation, see Fig. 3 and p. 462. 

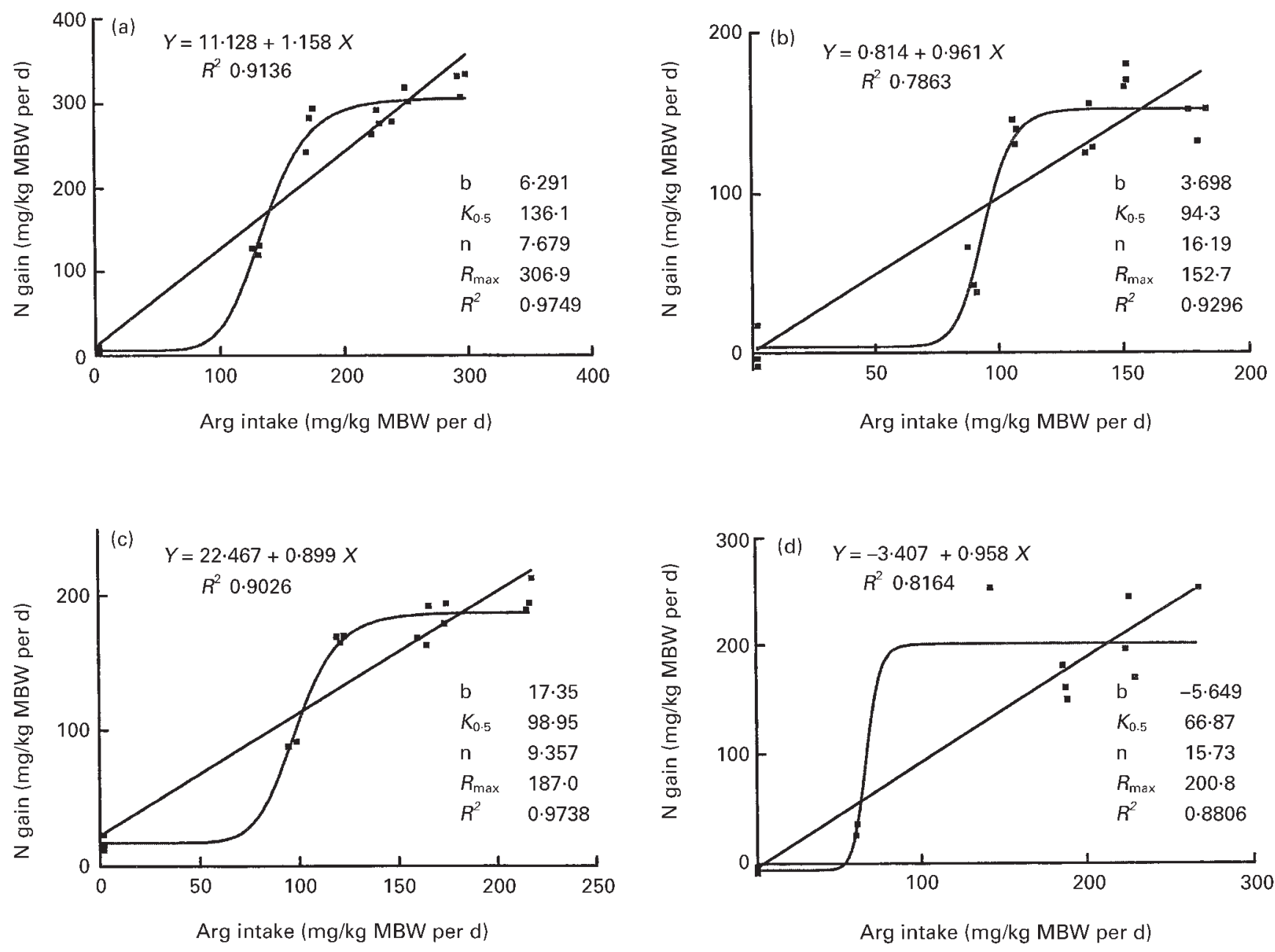

Fig. 4. Relationship between arginine (Arg) intake and nitrogen gain in the four species: (a) rainbow trout; (b) turbot; (c) seabass; (d) seabream. Both linear and the multivariate curve fittings (Mercer, 1982) for each set of data are provided along with the values for each parameter with the corresponding equations and the goodness $\left(R^{2}\right)$ for each model are provided. Each point represents the mean nitrogen gain of the fish per tank. MBW, metabolic body weight $\left(\left(\mathrm{IBW}^{0.75}+\mathrm{FBW}^{0.75}\right) / 2\right)$ where FBW and IBW represent final body weight and initial body weight respectively.

rainbow trout, Cho et al. (1992) have already used the fourparameter nutrient dose-response analysis to estimate the requirements. The relationship between Arg intake and $\mathrm{N}$ gain is in most occasions best described by the nonlinear model, as was already shown by Mambrini \& Kaushik (1995b) when estimating the SAA requirements of rainbow trout. Indeed, the strict application of the linear model as proposed by Fuller et al. (1989) for estimating the IAA requirements for maintenance in pigs would have been more reliable had we used diets (MA and $\mathrm{HA}^{-}$) with a greater degree of reduction in the IAA levels of the MP and HP diets. Irrespective of the model chosen, given that in trout, turbot and seabass, the intercept on the $y$ axis was positive, these is a clear indication of either nil or very low Arg requirements for maintenance in these species.

Table 6. Arginine (Arg) requirements for maintenance and protein growth in the four species calculated based on the method described by Fuller et al. (1989)*

\begin{tabular}{|c|c|c|c|}
\hline \multirow[b]{2}{*}{ Arg requirement for... } & \multirow{2}{*}{$\begin{array}{c}\mathrm{N} \text { balance } \\
\text { (mg Arg/kg MBW per d) }\end{array}$} & \multicolumn{2}{|c|}{ Unit gain } \\
\hline & & $\mathrm{mg} \mathrm{Arg} / \mathrm{g} \mathrm{N}$ gain & $\mathrm{mg} \mathrm{Arg/g}$ protein gain \\
\hline Rainbow trout & 0 & 863 & 138 \\
\hline Turbot & 0 & 1041 & 167 \\
\hline Gilthead seabream & 4.39 & 1040 & 166 \\
\hline European seabass & 0 & 1112 & 178 \\
\hline
\end{tabular}

MBW, metabolic body weight ((IBW $\left.\left.\mathrm{I}^{0.75}+\mathrm{FBW}^{0.75}\right) / 2\right)$; IBW, initial body weight $(\mathrm{kg})$; FBW, final body weight $(\mathrm{kg})$.

${ }^{*}$ For details of procedures, see p. 461, and for details of the calculation, see Fig. 4 and p. 462. 
Turbot require more $\mathrm{N}$ for maintenance $(127 \mathrm{mg} \mathrm{N} / \mathrm{kg}$ MBW per d) than the other fish species. This value is even superior to that pointed out for mammals (100 mg N/kg MBW per d; Reeds, 1988). Such high maintenance needs might explain the overall reputedly higher protein requirement of turbot. Available data suggest that dietary protein needs of flatfish such as turbot, sole (Solea vulgaris) and plaice (Pleuronectes platessa) are in the range of 55-65\% diet (Cowey et al. 1972; Cadena-Roa, 1983; Caceres-Martinez et al. 1984). N requirement for maintenance of juvenile rainbow trout grown at $17^{\circ} \mathrm{C}(38 \mathrm{mg} / \mathrm{kg}$ MBW per d) is comparable with data of Mambrini \& Kaushik (1995b): $52 \mathrm{mg} \mathrm{N} / \mathrm{kg}$ MBW per $\mathrm{d}$ and $26 \mathrm{mg} \mathrm{N} / \mathrm{kg}$ MBW per $\mathrm{d}$ in fish reared at $16^{\circ} \mathrm{C}$ or $8^{\circ} \mathrm{C}$ respectively. On the contrary, data on maintenance needs of gilthead seabream in the present study ( $85 \mathrm{mg} \mathrm{N} / \mathrm{kg}$ MBW per d) is lower than the $137.6 \mathrm{mg} \mathrm{N} /$ $\mathrm{kg} \mathrm{BW}^{0 \cdot 70}$ per d estimated by Lupatsch et al. (1998). For turbot, recalculation of $\mathrm{N}$ requirement for maintenance expressed as per average body weight per d was $470 \mathrm{mg} /$ $\mathrm{kg}$ average body weight $/ \mathrm{d}(y=-226.73+0.4823 x)$, a value considerably higher than that of $250 \mathrm{mg} \mathrm{N} / \mathrm{kg}$ per d, reported for plaice, another flatfish, by Cowey et al. (1972) and of other data on endogenous $\mathrm{N}$ excretion levels measured by Birkett (1969) and Jobling (1981). Further investigations need to be undertaken to explain the high $\mathrm{N}$ need for maintenance in turbot, especially since the basal energy requirements do not appear to be different between turbot and other pelagic fish (Kaushik, 1998). $\mathrm{N}$ requirement for unit $\mathrm{N}$ gain of rainbow trout and turbot are similar. The slope of the curve relating $\mathrm{N}$ intake and $\mathrm{N}$ gain was 0.46 in turbot and 0.44 in rainbow trout. This observation confirms the higher $\mathrm{N}$ retention efficiency in turbot compared with other farmed fish as already suggested by Caceres-Martinez et al. (1984), Dreanno (1994) and Dosdat et al. (1995).

Although $\mathrm{N}$ needs for maintenance of rainbow trout and seabass were similar, the higher $\mathrm{N}$ requirement for unit protein accretion of seabass $(0.404 v .0 .365 \mathrm{~g} / \mathrm{g}$ protein gain) could explain its higher dietary protein needs (Hidalgo \& Alliot, 1988; Dias et al. 1998; Peres \& Oliva-Teles, 1999). Data obtained here on the protein requirements of gilthead seabream are in accordance with those reported by Santinha et al. (1996).

The four species studied appear to have no or very low dietary Arg requirements for maintenance. Such observations have been made in ureotelic mammals such as man, pig and rat while in the uricotelic fowl, an amount of $81 \mathrm{mg}$ Arg/kg MBW per d was needed to maintain $\mathrm{N}$ equilibrium (Fuller et al. 1989). This remains an extremely intriguing observation for ammoniotelic species. Whether this would apply to all stages of the life cycle needs to be verified. In the juvenile stages studied here, whole body protein breakdown or Arg biosynthesis seems to provide enough Arg to meet maintenance requirement. Based on his data, Rodehutscord et al. (1995) suggested already that rainbow trout should be able to synthesise Arg when fed Arg-deficient diets. Studies underway to analyse the ornithine-urea cycle (OUC) enzyme activities should throw more light on this hypothesis of endogenous Arg synthesis. Huggins et al. (1969) detected all enzymes of the OUC in the liver of a number of teleosts. Dépêche et al. (1979) showed urea production by the OUC in juvenile trout but not in bigger fish. Cowey \& Walton (1989) detected only low activities of the OUC enzymes. Chiu et al. (1986) showed that Arg synthesis was functional in juvenile rainbow trout only under conditions of starvation. Servais (1994) detected ornithine carbamoyltransferase activity in the liver of rainbow trout, turbot, European seabass and gilthead seabream.

In mammals, Arg synthesis from glutamic acid via the intestinal-renal axis is known to occur (Wu \& Morris, 1998). In channel catfish (Ictalurus punctatus), dietary glutamic acid leads to increased plasma citrulline and to a lesser extent that of Arg, with possible reduction of dietary Arg requirement (Buentello \& Gatlin, 2000). In a subsequent study, the same authors (Buentello \& Gatlin, 2001) showed that there is endogenous synthesis of citrulline and suggested that this may serve as a possible de novo source of Arg. Whether similar Arg synthesis occurs in the four species studied here requires confirmation. In formulating the diets, care was taken not to modify the level of a single DAA such as glutamic acid to a great extent. Assessment of the activities of the OUC enzymes in the intestinal-renal axis in the species under study here might throw further light.

The comparison of Arg requirement for unit protein gain between the four species indicates a variation of about $20 \%$ between the four species studied. It is worth verifying this tendency with other IAA. As already mentioned by Mambrini \& Kaushik (1995a) and Cowey (1995), much variability has been recorded as regards Arg requirements of teleosts $(4-6 \mathrm{~g} \operatorname{Arg} / 16 \mathrm{~g} \mathrm{~N})$. Data for rainbow trout (Cho et al. 1992; Rodehutscord et al. 1995) and for European seabass (Tibaldi et al. 1994) suggest values of around $3 \cdot 8-4 \mathrm{~g} / 16 \mathrm{~g} \mathrm{~N}$. Luquet \& Sabaut (1974) suggested that the Arg requirement for gilthead seabream would be below $4 \mathrm{~g} /$ $16 \mathrm{~g} \mathrm{~N}$. Currently, no quantitative data on Arg needs of turbot are available. But, based on data obtained here, a dietary level of $5 \mathrm{~g} / 16 \mathrm{~g} \mathrm{~N}$ would appear to be a reasonable estimate for turbot. Turbot fed diet HP showed significantly $(P<0.05)$ lower $\mathrm{N}$ gain compared with fish fed HA (150 (SE 7) v. 170 (SE 5) mg N/kg MBW per d respectively; see Fig. 4). Arg is known to play a major role in mediating responses in the somatotropic axis (Swanson, 1990 ) and is also considered to be a potent growth promoter even in fish (Mommsen, 2001). But, a dietary excess of Arg does not seem to affect neither plasma insulin nor growth hormone levels in the Atlantic salmon (Salmo salar) (Lall et al. 1994). Considering the fact that high dietary Arg levels do not impair growth in the three other species, the adverse effect of excess Arg on growth of turbot requires further analysis.

Greater understanding of the metabolic pathway of Arg biosynthesis is also warranted to explain the apparent lack of Arg requirement for maintenance in at least three out of four species studied. Data obtained here correspond to juveniles under fast growing conditions. Further insight is needed on whether bigger fish or those subjected to a long-term Arg deficiency would react in a similar manner. 


\section{Acknowledgements}

This work was funded by the European Union under the FAIR programme (CT 98-3408). The authors gratefully acknowledge the technical assistance of H. Le Delliou and E. Rancati for biochemical analysis, and E. Desbruyères, C. Huelvan and J. Moriceau for diet preparation. V. Fournier acknowledges the receipt of a joint scholarship from INRA and Conseil Régional d'Aquitaine.

\section{References}

Association of Official Analytical Chemists (1984) Official Methods of Analysis, 12th ed., Washington, DC: Association of Official Analytical Chemists.

Birkett L (1969) The nitrogen balance in plaice, sole and perch. Journal of Experimental Biology 50, 375-386.

Buentello JA \& Gatlin DM III (2000) The dietary requirement of channel catfish (Ictalurus punctatus) is influenced by endogenous synthesis of arginine from glutamic acid. Aquaculture 188, 311-321.

Buentello JA \& Gatlin DM III (2001) Plasma citrulline and arginine kinetics in juvenile channel catfish, Ictalurus punctatus, given oral gabaculine. Fish Physiology and Biochemistry 24, $105-112$.

Caceres-Martinez C, Cadena-Roa M \& Métailler R (1984) Nutrition requirements of turbot (Scophthalmus maximus L.): 1- A preliminary study of protein and lipid utilisation. Journal of the World Mariculture Society 15, 191-202.

Cadena-Roa M (1983) Etude Expérimentale de l'Alimentation de la Sole (Solea vulgaris Q.) en Élevage Intensif (Experimental study of sole (Solea vulgaris $Q$.) nutrition in intensive rearing conditions). Phd Thesis, Université de Bretagne Occidentale.

Chiu YN, Austic RE \& Rumsey GL (1986) Urea cycle activity and arginine formation in rainbow trout (Oncorhynchus mykiss ). Journal of Nutritrion 116, 1640-1650.

Cho CY, Kaushik SJ \& Woodward B (1992) Dietary arginine requirement of young rainbow trout (Oncorhynchus mykiss). Comparative Biochemistry and Physiology 102A, 211-213.

Cowey CB (1994) Amino acid requirements of fish: a critical appraisal of present values. Aquaculture 124, 1-11.

Cowey CB (1995) Protein and amino acid requirements: A critique of methods. Journal of Applied Ichthyology 11, 199-204.

Cowey CB, Pope JA, Adron JW \& Blair A (1972) Studies on the nutrition of marine flatfish. The protein requirement of plaice (Pleuronectes platessa). British Journal of Nutrititon $\mathbf{2 8}$, 447-456.

Cowey CB \& Walton MJ (1989) Intermediary metabolism. In Fish Nutrition, 2nd ed., pp. 259-329 [JE Halver, editor]. San Diego, CA: Academic Press.

Dépêche J, Gilles R, Daufresne S \& Chiapello H (1979) Urea content and urea production via the ornithine-urea cycle pathway during the ontogenic development of two teleosts fishes. Comparative Biochemistry and Physiology 63A, 51-56.

Dias J, Alvarez MJ, Diez A, Arzel J, Corraze G, Bautista JM \& Kaushik SJ (1998) Regulation of hepatic lipogenesis by dietary protein/energy in juvenile European seabass (Dicentrarchus labrax). Aquaculture 161, 169-186.

Dosdat A, Metailler R, Tetu N, Servais E, Chartois H, Huelvan C \& Desbruyeres E (1995) Nitrogenous excretion in juvenile turbot, Scophthalmus maximus (L.), under controlled conditions. Aquaculture Research 26, 639-650.

Dreanno C (1994) Etude du Rôle des Apports Protéiques, Lipidiques et Glucidiques chez le Juvénile de Turbot (Scophthalmus maximus L.) (Dietary Protein, Lipid and Carbohydrate
Requirements in Juvenile Turbot (Scophthalmus maximus L.)). Mémoire de DEA, France: Université de Rennes.

Fuller MF, McWilliam R, Wang TC \& Giles LR (1989) The optimum dietary amino acid pattern for growing pigs. 2. Requirements for maintenance and for tissue protein accretion. British Journal of Nutrition 62, 255-267.

Hidalgo F \& Alliot E (1988) Influence of water temperature on protein requirement and protein utilization in juvenile seabass (Dicentrarchus labrax). Aquaculture 72, 115-129.

Huggins AK, Skutsch G \& Baldwin E (1969) Ornithine urea cycle enzymes in teleostean fish. Comparative Biochemistry and Physiology 28, 587-602.

ITCF (1991) STAT-ITCF. Paris: 4th Services des Études Statistiques.

Jobling M (1981) Some effects of temperature, feeding and body weight on nitrogenous excretion in young plaice (Pleuronectes platessa L.). Journal of Fish Biology 18, 87-96.

Kaushik SJ (1995) Protein nutrition and metabolism in fish. In Protein Metabolism and Nutrition, pp. 47-56 [AF Nunes, AV Portugal, JP Costa and JR Ribeiro, editors]. Portugal: INIA.

Kaushik SJ (1998) Nutritional bioenergetics for the estimation of wastes in non-salmonids. Aquatic Living Resources 11, 211-217.

Kaushik SJ \& Luquet P (1984) Relationship between protein intake and voluntary energy intake as affected by body weight with an estimation of maintenance needs in rainbow trout. Zeitschrift für Tierphysiologie, Tierernährung und Futtermittelkunde 51, 57-69.

Kaushik SJ, Luquet P \& Blanc D (1981) Usefulness of feeding protein and non-protein calories apart in studies on energyprotein interrelationships in rainbow trout. Annales de Zootechnie 30, 3-11.

Lall SP, Kaushik SJ, LeBail PY, Keith R, Anderson JS \& Plisetskaya E (1994) Quantitative arginine requirement of Atlantic salmon (Salmo salar) reared in sea water. Aquaculture 124, 13-25.

Lupatsch I, Kissil GW, Sklan D \& Pfeffer E (1998) Energy and protein requirements for maintenance and growth in gilthead seabream (Sparus aurata L.). Aquaculture Nutrition 4, $165-173$.

Luquet P \& Sabaut JJ (1974) Nutrition Azotée et Croissance chez la Daurade et la Truite (Dietary Nitrogen Utilisation and Growth in Gilthead Seabream and Rainbow Trout). Actes de Colloques. Colloques sur l'Aquaculture. Brest 1: 243-253. Brest, France: Ifremer.

Mackie AM \& Adron JW (1978) Identification of inosine and inosine $5^{\prime}$-monophosphate as the gustatory feeding stimulants for the turbot Scophthalmus maximus. Comparative Biochemistry and Physiology 60A, 79-83.

Mambrini M \& Kaushik SJ (1995a) Indispensable amino acid requirements of fish: correspondence between quantitative data and amino acids profiles of tissue proteins. Journal of Applied Ichthyology 11, 240-247.

Mambrini M \& Kaushik SJ (1995b) Effect of temperature on sulfur amino acid requirements for maintenance and growth of juvenile rainbow trout. In Protein Metabolism and Nutrition, pp. 117-122 [AF Nunes, AV Portugal, JP Costa and JR Ribeiro, editors]. Portugal: INIA.

Mercer LP (1982) The quantitative nutrient-response relationship. Journal of Nutrition 112, 560-566.

Mommsen TP (2001) Paradigms of growth in fish. Comparative Biochemistry Physiology 129B, 207-219.

Nutrition Research Council (1993) Nutrient Requirements of Domestic Animals. In Nutrient requirements of fish. Washington, DC: National Academy Press.

Peres H \& Oliva-Teles A (1999) Influence of temperature on 
protein utilization in juvenile European seabass (Dicentrarchus labrax). Aquaculture 170, 337-348.

Reeds PJ (1988) Nitrogen metabolism and protein requirements. In Comparative Nutrition, pp. 52-72 [K Blaxter and I MacDonald, editors]. London: John Libbey and Co. Ltd.

Rodehutscord M, Becker A, Pack M \& Pfeffer E (1997) Response of rainbow trout (Oncorhynchus mykiss) to supplements of individual essential amino acids in a semipurified diet, including an estimate of the maintenance requirement for essential amino acids. Journal of Nutrition 127, 1166-1175.

Rodehutscord M, Jacobs S, Pack M \& Pfeffer E (1995) Response of rainbow trout (Oncorhynchus mykiss) growing from 50 to $170 \mathrm{~g}$ to supplements of either L-arginine or L-threonine in a semipurified diet. Journal of Nutrition 125, 970-975.

Rodehutscord M, Mandel S \& Pfeffer E (1994) Reduced protein content and use of wheat gluten in diets for rainbow trout: Effects on water loading with $\mathrm{N}$ and P. Journal of Applied Ichthyology 10, 271-273.

Santinha PJM, Gomes EFS \& Coimbra JO (1996) Effects of protein level of the diet on digestibility and growth of gilthead sea bream, Sparus auratus L. Aquaculture Nutrition 2, 81-87.
Servais F (1994) Caractérisation des Rejets Azotés Engendrés par le Jeune Turbot, Scophthalmus maximus, Comparison avec d'autres Espèces d'Intérêt Aquacole (Nitrogen Excretion in Juvenile Turbot and Other Cultured Fishes). Angers, France: Ecole Supérieure d'Agriculture d'Angers 93p.

Swanson DR (1990) Somatomedin C and arginine: implicit connections between mutually isolated literatures. Perspectives in Biology and Medicine 33, 157-186.

Tacon AGJ \& Cowey CB (1985) Protein and amino acid requirements. In Fish Energetics: New Perspectives, pp. 155-183 [P Tytler and P Calow, editors]. London: Croom Helm.

Tibaldi E, Tulli F \& Lanari D (1994) Arginine requirement and effect of different dietary arginine and lysine levels for fingerlings sea bass (Dicentrarchus labrax). Aquaculture 127, 207-218.

Visek WJ (1986) Arginine needs, physiological state and usual diets: a reevaluation. Journal of Nutrition 116, 36-46.

Wilson RT (1989) Amino acids and proteins. In Fish Nutrition, 2nd ed., pp. 111-159 [JE Halver, editor]. San Diego, CA: Academic Press.

Wu G \& Morris SM (1998) Arginine metabolism: nitric oxide and beyond. Biochemical Journal 336, 1-17. 